\title{
Schistosomiasis Mansoni in Areas of Low Transmission. Epidemiological Characterization of Venezuelan Foci
}

\author{
B Alarcón de Noya/ ${ }^{+}$, R Ruiz, C Colmenares, S Losada, IM Cesari*, J Toro**, O Noya
}

\begin{abstract}
Sección de Biohelmintiasis, Instituto de Medicina Tropical and Cátedra de Parasitología, Escuela de Medicina "Luis Razetti”, Facultad de Medicina, Universidad Central de Venezuela, Apartado Postal 47706, Los Chaguaramos, Caracas 1041-A, Venezuela *Centro de Microbiología y Biología Celular, Instituto Venezolano de Investigaciones Científicas, Caracas, Venezuela **Fundasalud del Estado Carabobo, Venezuela
\end{abstract}

Severe schistosomiasis is a rare event in Venezuela nowadays, after a successful national campaign by the Schistosomiasis Control Program. Unfortunately, this program has practically disappeared, and snail surveillance in field is not a priority, anymore. Thus, schistosomiasis has become a neglected disease in this country. However, surveys in different populations from the endemic area have shown particular epidemiological features described herein. In five communities we evaluated 2,175 persons and searched for the presence of Biomphalaria glabrata snails. Some markers were used for classifying schistosomiasis foci: mean age of the persons with Schistosoma mansoni eggs in the stools, serological tests, presence of B. glabrata snails, and intensity of infection. Places without B. glabrata snails and with few schistosomiasis cases were defined as "past transmission sites"; a site with abundant snails but few cases was defined as "potential risk"; "new transmission" foci were characterized by the presence of infected snails and young people passing eggs in the stools. A "re-emergent" focus has shared these last features, showing in addition a place where schistosomiasis had been reported before. Recent evidences of active transmission with the increasing dispersion of $\mathrm{B}$. glabrata snails, point out the necessity for the re-establishment of the Schistosomiasis Control Program in Venezuela.

Key words: Schistosoma mansoni - prevalence - low transmission - Venezuela

At present, when the epidemiological features of schistosomiasis are changing from high to low prevalence, it is necessary to monitor endemic areas continuously. For years we have used several approaches to control schistosomiasis. These measures significantly decreased prevalence and morbidity, becoming Venezuela a country with low transmission (Alarcón de Noya et al. 1999). The Venezuelan endemic area has remained as a small region of $15,000 \mathrm{~km}^{2}$, embracing the states Aragua, Carabobo, Guárico, Miranda and Vargas, and where active human cases and infected snails continue to reappear when epidemiological surveys, are carried out. Those characteristics difficult the identification of schistosomiasis cases, and then treatment of individuals and communities (Feldmeier \& Poggense 1993).

A concomitant process of political and administrative decentralization of the country have delegated to the regional authorities the responsibilities of the health programs, limiting the efficiency achieved by the former Schistosomiasis Control Program. As in other parts of the world where schistosomiasis is considered a low impact public health disease, a re-evaluation of the actual situation of

Financial support: "Programa de Control de Enfermedades Endémicas de Malariología”, World Bank (PCEE/PNUD) and "Consejo de Desarrollo Científico y Humanístico".

${ }^{+}$Corresponding author. Fax: +58-212-6053563. E-mail: alarconb@camelot.rect.ucv.ve.

Received 18 June 2002

Accepted 15 August 2002 transmission must be reinforced. From this point of view, we have recently classified some of Venezuelan foci using traditional tools and the definition of schistosomiasis cases recently proposed (Ruiz et al. 1999).

The correct diagnosis of schistosomiasis is a crucial aspect, since the different methods used so far have shown diverse limitations (Alarcón de Noya et al. 1992). The present work evaluates the current situation of some schistosomiasis foci in Venezuela, and classify them according to some epidemiological parameters. These criteria could be applied to countries with low transmission or to those going toward this phase of transmission.

\section{MATERIALS AND METHODS}

Study population - This work was carried out in Caraballeda (Vargas state), La Curía and La Candelaria (Aragua state), Los Mangos, José Leonardo Chirinos and Belén (Carabobo state) between 1998 and 2000. A house by house visit was performed in order to promote the participation of all communities and to carry out the epidemiologic interviews, and the collection of stool and blood samples. Only volunteers were included in the study and children required be accompanied by their parents. After laboratory tests were achieved, results were distributed in the communities. Patients with schistosomiasis or another intestinal parasitic disease were treated with the specific chemotherapy.

Stool examination - Feces were evaluated by KatoKatz method (Katz et al. 1972). Two Kato Katz thick smears were prepared for each stool sample and read blindly by different observers. Individual egg output of $S$. mansoni was expressed as eggs per gram of feces (e.p.g.) (arithmetic mean of all eggs counts multiplied by 24) (WHO 
1985). Three infection categories were considered: mild ( $\leq 100$ e.p.g.), moderate (101-400 e.p.g.) and severe (> 400 e.p.g.) (WHO 1993).

Immunological tests - Venous blood was taken from all examinees. Sera obtained by centrifugation was stored at $-80^{\circ} \mathrm{C}$ and thereafter analyzed for serologic tests.

Enzyme linked immunosorbent assay (ELISA), with sodium metaperiodate (SMP-ELISA) - This test was performed according Alarcón de Noya et al. (2000), using 2.5 $\mu \mathrm{g} / \mathrm{ml}$ soluble egg antigen (SEA) in carbonate-bicarbonate buffer, $\mathrm{pH}$ 9.6, for sensitization. Nunc-Immuno Maxi Sorp plates were exposed to $1.5 \mathrm{mM}$ sodium metaperiodate for $1 \mathrm{~h}$ in the dark after SEA-sensitization. Later on, sera from patients were added, following thereafter the steps of a conventional ELISA (Voller et al. 1976).

Circumoval precipitin test (COPT) - This was carried out according to Spencer et al. (1991). The test was considered positive when $10 \%$ or more of eggs were observed with precipitation on its surface in form of refringente globes or chains, when incubated with patient's sera.

Alkaline phosphatase immunoassay (APIA) - APIA was performed according to Pujol and Cesari (1990).

Schistosomiasis cases - Once the laboratory exams were processed, we decided to consider as "cases" of schistosomiasis (Ruiz et al. 1999) those people with: (a) eggs of $S$. mansoni in stools; these patients have positive COPT, SMP-ELISA, and APIA; (b) persons without $S$. mansoni eggs in stools but with positive COPT, who have not received previous anti-S. mansoni chemotherapy in the last 12 months; (c) persons without $S$. mansoni eggs in stools, with negative COPT, but with both SMPELISA and APIA (immunoassay tests) positive simultaneously in people without previous chemotherapy against schistosomiasis.

Snail sampling - Using an appropriate net, the shore of small water bodies close to the different populations were searched for Biomphalaria glabrata snails. Detection of infection was achieved by weekly exposing the individual snails to natural light and examining the water afterwards.

\section{RESULTS}

La Candelaria, La Curía and Belén are rural communities where inhabitants are at least partially occupied in agriculture under irrigation systems. These are mountainous areas, with a mean temperature of $25-27^{\circ} \mathrm{C}$ during the whole year. There are some extensions of humid forests along the mountains that are in a range of altitude between 500 and 1,900 m over the sea level. The rivers that irrigate these areas are apparently not very polluted with organic or industrial waste.

Caraballeda and José Leonardo Chirinos correspond to urban marginal populations, in which the water courses have been reduced to collectors of served waters. In these communities, especially in José Leonardo Chirinos, the sanitary conditions are precarious, with no collection of sewage, or gathering of garbage. Most of the houses are not well built, in which people live overcrowded. Earth floors are frequent and in occasions the water of the near drainage enters the houses. In these sites, great quantity of flies, other insects, and dogs were present and bare foot people were observed.

A total of 2,175 persons were interviewed in the visited areas, but for the present work we dealed with 1,493 persons to whom Kato-Katz, COPT, SMP-ELISA and APIA were achieved.

Prevalence of schistosomiasis cases in each community - The presented data demonstrates that the general schistosomiasis prevalence in the evaluated areas was $13.5 \%(\mathrm{n}=1,493)$.

From 202 schistosomiasis cases, 38 (18.8\%) eliminated S. mansoni eggs in feces; $111(55 \%)$ showed a positive COPT, and $53(26.2 \%)$ had SMP-ELISA and APIA tests simultaneously positives, with negative results in the COPT and feces. Table I shows the prevalence in the areas under investigation, the age average of the infected persons, and their relationship with the diverse methods used for the diagnosis which determine the definition of a case of schistosomiasis. In general, the age average of the schistosomiasis cases in the studied areas was 28 years old and the stool examination detected only $18.8 \%$ of the total cases.

Criterion I. Positive group by stool examination The presence of S. mansoni eggs in the stools was diagnosed in 38 patients in the five communities, which represents $18.8 \%(\mathrm{n}=202)$ of the cases. The remaining $81.2 \%$ $(n=202)$ of patients was identified by serology (Table I). These patients had, an average 25 years old.

The intensity of infection of all the evaluated patients and their relation with the community and age can be seen in Table II: $76.3 \%$ (29 patients) eliminated less than $101 S$. mansoni e.p.g. in feces, and $23.7 \%$ (9 persons) presented moderate infections. There were no persons with severe infections. The patients of Belén (age average 20 years), and those of J. L. Chirinos (21 years) were younger than those of Caraballeda (39 years).

It was found that the mean e.p.g. of feces in Caraballeda was 44 (range: 24-101), in J. L. Chirinos 24, and in Belén 94 (range: 24-384 e.p.g.). The general mean of intensity was 78 e.p.g. (range: among 24-384 e.p.g.).

Criterion II. Persons positive by COPT - From 202 persons with schistosomiasis, $111(55 \%)$ had positive COPT. They were simultaneously positive by SMP-ELISA and had a negative exam of feces (Table I). The age average of this group was 26 years old. Among the 111 patients diagnosed under this criteria, 31 (27.9\%) were younger than 16 years old (data not shown).

Criterion III. Persons with positive SMP-ELISA and APIA - From the 202 people with S. mansoni infection, 53 (26.2\%) had no eggs in the stool and were negative for COPT but they were simultaneously positive for SMPELISA and APIA. From this group of patients, $13.2 \%$ were under 16 years old and $71.7 \%$ older than 25 (data not shown). In Caraballeda, La Candelaria and La Curía there were no cases with less than 18 years by this approach. The age average of the positive patients for SMP-ELISA/ APIA was 34 years old.

Snail sampling - No Biomphalaria sp. snails were found in Caraballeda, and in La Candelaria. However, in Caraballeda there were snails of the genus Thiara and abundant fecal contamination in the riverbanks of the San Julian river. The inhabitants of this community frequently 
used the water of this river as much with recreational purposes and for their personal hygiene.

In La Candelaria community, it was not possible to find B. glabrata, neither people with $S$. mansoni eggs in stools. After the study was carried out, we were informed that shortly before, the personnel of Rural Endemic Diseases Division had applied molluscicides and indicated massive treatment with praziquantel in this site.

In San Mateo, very near La Curía, there were abundant B. glabrata snails. We examined 3,000 snails and no cercariae were found after 45 days of captivity. The surroundings of the gulches and rivers of the area of La Curía are frequently used by the population and they showed high fecal contamination.

In J. L. Chirinos, the search of B. glabrata was positive, and $1 \%$ of the captured snails eliminated S. mansoni cercariae. B. straminea was also found, but they did not show $S$. mansoni infection.

In Belén, also $1 \%$ of the B. glabrata were eliminating $S$. mansoni cercariae. The gulches and rivers of the area are frequently used, especially by children, and fecal contamination was observed in the riverbanks.

\section{DISCUSSION}

The prevalence of the infection is variable in the Venezuelan endemic areas for schistosomiasis and it affects different age-groups according to the dynamics of transmission. We have used some epidemiological criteria such as the mean age of schistosomiasis cases, the intensity of infection and the presence of infected or uninfected $B$. glabrata snails, in order to characterize the endemic foci.
On the basis of the three laboratory diagnostic applied for the definition of each case of schistosomiasis and the use of the epidemiological parameters mentioned, results showed particular characteristics for each community.

In Caraballeda (Vargas state), the schistosomiasis prevalence was $21.6 \%$, mainly due to people older than 26 years, being the age average 35 years old. In the early 1980 s, the prevalence, as determined by coprologic studies was $34.7 \%$, affecting people from 6 to 20 years of age. In that opportunity, $28.2 \%$ of $B$. glabrata snails eliminated $S$. mansoni cercariae (Alarcón de Noya et al. 1987). Currently, the riverbanks of the main river of Caraballeda is contaminated with a great quantity of organic and inorganic waste and fecal contamination, and at present there is no schistosome transmission in this area. There is not B. glabrata, but Melanoides sp. Previous studies already pointed out that Thiaridae had displaced Biomphalaria from the Venezuelan coast (Pointier et al. 1994) as already described in other endemic areas of the Caribbean (Pointier 1993). In spite of absence of schistosomiasis vectors since the beginning of the 1980s in Caraballeda (Alarcón de Noya et al. 1999), there was still $21.4 \%$ of the examined people, eliminating $S$. mansoni eggs in feces 20 years later (Table I). Another $61.9 \%$ of the infected persons in this area, had active infection for $S$. mansoni as demonstrated by positive COPT (Criterion II) (mean age 32 years old, range: 15-67 years). The prevalence age curve was different from that found in active transmission sites, that is, most cases concentrates in adults rather than children. A third group of persons considered with schistosomiasis from Caraballeda (16.7\%), corresponded with individuals

TABLE I

Schistosomiasis case prevalence and age average according to community. Venezuela, 1998-2000

\begin{tabular}{|c|c|c|c|c|c|c|c|c|c|c|c|c|c|c|}
\hline \multirow[b]{3}{*}{ Town } & \multirow[b]{3}{*}{ State } & \multirow{3}{*}{$\begin{array}{l}\text { Evaluated } \\
\text { persons }\end{array}$} & \multicolumn{3}{|c|}{$\begin{array}{c}\text { Stool examination } \\
(+)\end{array}$} & \multicolumn{3}{|c|}{$\begin{array}{c}\mathrm{COPT} \\
(+)\end{array}$} & \multicolumn{3}{|c|}{$\begin{array}{c}\text { SMP-ELISA (+) } \\
\text { APIA (+) }\end{array}$} & \multicolumn{3}{|c|}{ Total } \\
\hline & & & \multicolumn{2}{|c|}{ Cases } & \multirow{2}{*}{$\begin{array}{c}\bar{X} \\
\text { Age }\end{array}$} & \multicolumn{2}{|c|}{ Cases } & \multirow{2}{*}{$\begin{array}{c}\bar{X} \\
\text { Age }\end{array}$} & \multicolumn{2}{|c|}{ Cases } & \multirow{2}{*}{$\begin{array}{c}\bar{X} \\
\text { Age }\end{array}$} & \multicolumn{2}{|c|}{ Prevalence } & \multirow{2}{*}{$\begin{array}{l}\bar{X} \\
\text { Age }\end{array}$} \\
\hline & & & $\mathrm{n}$ & $(\%)$ & & $\mathrm{n}$ & $(\%)$ & & $\mathrm{n}$ & $(\%)$ & & $\mathrm{n}$ & $(\%)$ & \\
\hline Caraballeda & Vargas & 194 & 9 & 21.4 & 39 & 26 & 61.9 & 32 & 7 & 16.7 & 41 & 42 & 21.6 & 35 \\
\hline Candelaria & Aragua & 325 & 0 & 0 & - & 26 & 56.5 & 38 & 20 & 43.5 & 41 & 46 & 14.2 & 39 \\
\hline Curía & Aragua & 38 & 0 & 0 & - & 1 & 100 & 24 & 0 & 0 & - & 1 & 2.6 & 24 \\
\hline J. L. Chirinos & Carabobo & 239 & 2 & 8.0 & 21 & 13 & 52 & 17 & 10 & 40 & 19 & 25 & 10.5 & 18 \\
\hline Belén & Carabobo & 697 & 27 & 30.7 & 20 & 45 & 51.1 & 20 & 16 & 18.2 & 32 & 88 & 12.6 & 22 \\
\hline Total & & 1,493 & 38 & 18.8 & 25 & 111 & 55 & 26 & 53 & 26.2 & 34 & 202 & 13.5 & 28 \\
\hline
\end{tabular}

COPT: circumoval precipitin test; SMP-ELISA: sodium metapioridate-enzime linked immunosorbent assay; APIA: alkaline phosphatase immunoassay

TABLE II

Intensity of the infection and age average of schistosomiasis cases according community. Venezuela, 1998-2000

\begin{tabular}{|c|c|c|c|c|c|c|c|c|}
\hline \multirow[b]{2}{*}{ Town } & \multicolumn{2}{|c|}{ Mild } & \multicolumn{2}{|c|}{ Moderate } & \multicolumn{4}{|c|}{ Total } \\
\hline & $\mathrm{n}(\%)$ & $\bar{X}$ Age & $\mathrm{n}(\%)$ & $\overline{\mathrm{X}}$ Age & $\mathrm{n}$ & $(\%)$ & $\bar{X}$ e.p.g. & $\overline{\mathrm{X}} \mathrm{Age}$ \\
\hline Caraballeda & 8 & 39 & 1 & 39 & 9 & 23.7 & 44 & 39 \\
\hline J. L. Chirinos & 2 & 21 & 0 & - & 2 & 5.3 & 24 & 21 \\
\hline Belén & 19 & 21 & 8 & 19 & 27 & 71.1 & 94 & 20 \\
\hline Total & $29(76.3)$ & 26 & $9(23.7)$ & 22 & 38 & 100 & 78 & 25 \\
\hline
\end{tabular}

e.p.g. : mean of eggs per gram of feces; WHO (1985) 
41 year-old in average, that had simultaneously positive SMP-ELISA and APIA (Criterion III). Then, based on the different epidemiological parameters, this site was considered as a "low risk" focus.

In La Candelaria, 46 persons from 325 evaluated (14.2\%) were positive for schistosomiasis by serological methods. Considering that there were no snails of the genus Biomphalaria in the area, the age of the patients, and the inexistence of persons eliminating S. mansoni eggs in the stools, we inferred the absence of schistosome transmission in 1998 when the area was evaluated. After we concluded the study in La Candelaria, we were informed that chemotherapy against schistosomiasis and molluscicides had been administered four months before. Also, based on these parameters this locality could be defined of "unknown risk".

In La Curía, another rural community of the Aragua state, only a 24 years-old woman ( $2.6 \%$ from 38 evaluated persons) presented schistosomiasis by Criterion II. In San Mateo, near to La Curía, there were abundant uninfected B. glabrata snails. This fact, plus the absence of people eliminating $S$. mansoni eggs in stools and the age of the patient of this community, suggest that there was not transmission in this site, but due to the proximity of important urban centers, as La Victoria and Maracay, a periodic supervision must be carried out. It is not unlikely that people with schistosomiasis coming from other communities, move to this area increasing the current risk. La Curía and close areas represent an area of "potential risk", with the possibility of reactivation of this area (Mott et al. 1990).

The neighborhood J. L. Chirinos is located at the south of the city of Valencia, an important industrialized center where there is great migration from the inland of Carabobo and other Venezuelan states. J. L. Chirinos is a marginal community, where there is an intense water pollution, the population is in frequent contact with the water, and there is not a sewage system. In J. L. Chirinos we found $B$. glabrata eliminating $S$. mansoni cercariae. The transmission of schistosomiasis in J. L. Chirinos is guaranteed since there are very young people eliminating eggs of $S$. mansoni in the feces. The eco-epidemiological and social conditions, together with the continuous migration of people, allow to consider this community as an emergent area of schistosomiasis with great risk of expansion. As proposed by Mott et al. (1990) for other endemic situations, it is possible that the migration of people from other areas collaborated to create this "new transmission" focus. The new urban foci of schistosomiasis are places of intense transmission with frequent water contact, high levels of fecal contamination and population density, where the migrants have transferred their culture and ecology to the urban means (Mott et al. 1990).

In Belén, 88 (12.6\%) persons were positive, 27 out of them having $S$. mansoni eggs in feces, with an age average of 20 years old. In Belén infected B. glabrata snails were captured also. In this site, the conditions were favorable for the maintenance of schistosomiasis because a considerable percentage of young people were eliminating $S$. mansoni eggs in feces, plus the presence of the vector under favorable ecological and poor social conditions. The children of Belén had frequent water contact with the river of the area, mainly for recreational reasons. Since Belén is a known schistosomiasis town by the Control Program and where measures for human and snails control had been applied, this area was considered as a "re-emerging" foci.

Summarizing all the data obtained from this study, an epidemiological qualification of foci is shown in Table III. The general prevalence of schistosomiasis in the studied areas was $13.5 \%$. The most affected age-group corresponds to the age range of 11-30 years old (Ruiz et al. 1999). Only $18.8 \%$ of the positive patients could be diagnosed through the exam of feces. This suggests that in Venezuela we can not discard schistosomiasis only by the coprologic tests, since the parasitologic study has a poor efficiency to predict absence of infection, and it is necessary to employ immunodiagnosis for the recognition of schistosomiasis cases (Alarcón de Noya et al. 1992, Ruiz et al. 1999).

In most populations studied, the prevalence of schistosomiasis is higher in young than adults (Arap-

TABLE III

General characteristics of schistosomiasis foci in Venezuela, 1998-2000

\begin{tabular}{|c|c|c|c|c|c|c|}
\hline & Caraballeda & La Candelaria & La Curía & J. L. Chirinos & Belén & General \\
\hline Prevalence $(\%)$ & 21.6 & 14.2 & 2.6 & 10.5 & 12.6 & 13.5 \\
\hline $\begin{array}{l}\text { Age average } \\
\text { of cases }\end{array}$ & 35 & 39 & 24 & 18 & 22 & 28 \\
\hline $\begin{array}{l}\text { Persons (\%) eliminating } \\
\text { Schistosoma mansoni eggs }\end{array}$ & 21.4 & 0 & 0 & 8 & 30.7 & 18.8 \\
\hline Mean egg output (e.p.g.) & 44 & 0 & 0 & 24 & 94 & 78 \\
\hline Snail collection & $\begin{array}{l}\text { No } \\
\text { B. glabrata }\end{array}$ & $\begin{array}{l}\text { No } \\
\text { B. glabrata }\end{array}$ & $\begin{array}{l}\text { B. glabrata } \\
\text { negative }\end{array}$ & $\begin{array}{l}\text { B. glabrata } \\
\text { positive } 1 \%\end{array}$ & $\begin{array}{l}\text { B. glabrata } \\
\text { positive } 1 \%\end{array}$ & $\begin{array}{l}\text { B. glabrata } \\
\text { positive }\end{array}$ \\
\hline $\begin{array}{l}\text { Epidemiological } \\
\text { characteristics } \\
\text { of foci }\end{array}$ & $\begin{array}{l}\text { Without } \\
\text { transmission; } \\
\text { low risk }\end{array}$ & $\begin{array}{l}\text { Without } \\
\text { transmission; } \\
\text { unknown risk }\end{array}$ & $\begin{array}{l}\text { Without } \\
\text { transmission; } \\
\text { potential risk }\end{array}$ & $\begin{array}{c}\text { Active } \\
\text { transmission; } \\
\text { new focus }\end{array}$ & $\begin{array}{c}\text { Active } \\
\text { transmission; } \\
\text { reactivation }\end{array}$ & \\
\hline
\end{tabular}

$\mathrm{n}=1,493 ; a$ : percentage from total schistosomiasis cases of each community. 
Siongok et al. 1976, Jordan 1980, Butterworth \& Hagan 1987, Sturrok 1989, Fulford et al. 1992, Butterworth 1994, Gryseels 1994, Wiest 1996, Hagan et al. 1998, Woolhouse 1998). Prevalence and intensity of infection reach their peaks in early ages in areas where transmission is high, whereas in areas of low transmission both parameters remain low (Fulford et al. 1992, Wiest 1996, Woolhouse 1998) and the more affected are the grown-ups (Woolhouse 1998). This is known as the "Peak Shift" effect (Hagan et al. 1998, Woolhouse 1998). In the present investigation carried out in endemic Venezuelan areas, the peak of infection was high in young people in areas where there was transmission (Belén and J. L. Chirinos) whereas it shifted to grown-ups in areas where the transmission was absent (Candelaria, Curía, Caraballeda), as described previously in the medical literature (De Vlas \& Gryseels 1991, Hagan et al. 1998).

In this study there was a predominant prevalence of mild infections (76.3\%), and the cases of moderate infections came mainly from children and young adults.

The prevalence and the intensity of the infection are two parameters that have important implications in control. Control measures must point out to treat young individuals in populations with high transmission levels (Woolhouse 1998); however, when control measures are applied, it is necessary to take in consideration that age and prevalence curves change, affecting more the grownups (Woolhouse 1998) as it was observed in Caraballeda, La Candelaria and La Curía.

Immunodiagnosis could detect most patients positive for schistosomiasis in the evaluated Venezuelan endemic areas $(81.2 \%)$. When some of this people with negative coprologic exam had repeated their stool examinations, they revealed the presence of scarce $S$. mansoni eggs in the fourth or sixth exam, demonstrating in this way, the importance of immunodiagnosis in areas of low intensity of infection.

Considering the observations from our five communities, we can conclude that two localities had no schistosomal transmission (Caraballeda and La Candelaria), one was without transmission but under a potential risk because the high density of snails found (La Curía), and two localities with active schistosome transmission: a newly established focus (J.L. Chirinos) and a reemerging one (Belén). These results indicate that countries with low schistosomiasis transmission need to evaluate places with new and old transmission for monitoring the presence of the disease.

Caraballeda surveillance was done before the 1999' tragedy of Vargas state due to massive floods and landslides. Currently, the geography has changed completely and most of the survivors were moved to other endemic and non-endemic localities of the country. Since Biomphalaria sp. has been found in several areas of Venezuela (Alarcón de Noya et al. 1999), it is indispensable to keep the surveillance of this parasitic infection since some of the migrants from Caraballeda are still passing S. mansoni eggs in the stools, increasing the risk of dispersion of the schistosome transmission in the places where the vector is present. On the other hand, as the ecological conditions have changed deeply, and all fauna has disappeared, its is necessary to monitor the San Julian river every five years in order to avoid the re-establishment of B. glabrata, since the competitor Melanoides snails have disappeared.

\section{ACKNOWLEDGEMENTS}

To all members of the communities of Caraballeda, La Candelaria, La Curía, J. L. Chirinos and Belén for their voluntary cooperation. To Hector Contreras, Cesar Matos, Benjamín Zerpa $(\dagger)$ and Enrique Utrera for their invaluable help in the snail collection. We deeply dedicate this work to Caraballeda people who suffered or disappeared during the 1999 tragedy.

\section{REFERENCES}

Alarcón de Noya B, Balzán C, Arteaga C, Cesari I, Noya O 1999. The last fifteen years of schistosomiasis in Venezuela: features and evolution. Mem Inst Oswaldo Cruz 94: 139-146.

Alarcón de Noya B, Colmenares C, Lanz H, Caracciolo MA, Losada S, Noya O 2000. Schistosoma mansoni: immunodiagnosis is improved by sodium metaperpiodate which reduces cross-reactivity due to glycosylated epitopes of soluble egg antigen. Exp Parasitol 95: 106-112.

Alarcón de Noya B, Noya O, Balzán C, Cesari IM 1992. New approach for the control and eradication of schistosomiasis in Venezuela. Mem Inst Oswaldo Cruz 87: 227-231.

Alarcón de Noya B, Noya O, de Urbáez R, Risques J 1987. Reactivación del foco bilharziano de Caraballeda en 19801983. Bol Dir Malariol Saneamiento Amb 2: 86-93.

Arap-Siongok TK, Mahmoud AAF, Ouma JH, Warren K, Muller AS, Handa AK, Houser HB 1976. Morbidity in schistosomiasis mansoni in relation to intensity of infection: study of to community in Machakos, Kenya. Am J Trop Med Hyg 25: 273-284.

Butterworth AE 1994. Human immunity to schistosomes: some questions. Parasitol Today 10: 378-380.

Butterworth AE, Hagan P 1987. Immunity in human schistosomiasis. Parasitol Today 3: 11-16.

De Vlas SJ, Gryseels B 1991. Underestimation of Schistosoma mansoni prevalences. Parasitol Today 8: 274-277.

Feldmeier H, Poggense G 1993. Diagnostic techniques in schistosomiasis control. A review. Acta Trop 52: 205-220.

Fulford AJ, Butterworth AE, Sturrock RF, Ouma JH 1992. On the use of age-intensity data to detect immunity to parasitic infections, with special reference to Schistosoma mansoni in Kenya. Parasitology 105: 219-227.

Gryseels B 1994. Human resistance to Schistosoma infections: age or experience? Parasitol Today 10: 380-384.

Hagan P, Ndhlovu PD, Dunne DW 1998. Schistosome immunology: more questions than answers. Parasitol Today 14: 407-412.

Jordan P 1980. Epidemiology and control of schistosomiasis. British Med Bull 28: 55-59.

Katz N, Chaves A, Pellegrino J 1972. A simple device for quantitative stool thick-smear technique in schistosomiasis mansoni. Rev Inst Med Trop São Paulo 14: 397-400.

Mott KE, Desjeux P, Moncayo A, Ranque P, Raad P 1990. Parasitic diseases and urban development. Bull WHO 68: 691-698.

Pointier JP 1993. The introduction of Melanoides tuberculata (Mollusca: Thiaridae) to the island of Saint Lucia (West Indies) and its role in the decline of Biomphalaria glabrata, the snail intermediate host of Schistosoma mansoni. Acta Trop 54: 13-18.

Pointier JP, Incani RN, Balzan C, Chrosciechowski P, Prypchan S 1994. Invasion of rivers of the Littoral Central Región of 
Venezuela by Thiara granifera and Melanoides tuberculata (Mollusca: Prosobranchia: Thiaridae) and the absence of Biomphalaria glabrata snail host of Schistosoma mansoni. The Nautilus 107: 124-128.

Pujol FH, Cesari IM 1990. Antigenicity of adult Schistosoma mansoni alkaline phosphatase Parasite Immunol 12: 189198.

Ruiz R, Alarcón de Noya B, Colmenares C, Losada S, Contreras R, Cesari IM, Zerpa B, Utrera E, Sierra C, Sojo J, Noya O 1999. El diagnóstico clínico y de laboratorio como criterios en la definición de "casos" de esquistosomiasis en áreas de baja transmisión. Acta Cient Venezol 50: 346.

Spencer L, Alarcón de Noya B, Noya O, Masrrona O 1991. Análisis comparativo entre la Prueba de Precipitación Circumoval y ELISA con antígenos crudos para el diagnóstico de la schistosomiasis en Venezuela. GEN 45: 77-83.
Sturrok RF 1989. The control of schistosomiasis: epidemiological aspects of reinfection. Mem Inst Oswaldo Cruz 84: 134-148.

Voller A, Barlett A, Bidwell D 1976. Enzyme immunoassays for parasitic diseases. Trans $R$ Soc Trop Med Hyg 70: 98105.

WHO-World Health Organization 1985. Diagnosis techniques for intestinal parasitic infections (IPI) applicable to primary health care (PHC) services. Unpublished WHO Document PDP/85.2.

WHO-World Health Organization 1993. The Control of Schistosomiasis, WHO Technical Report Series, Geneva.

Wiest PM 1996. The epidemiology of morbidity of schistosomiasis. Parasitol Today 12: 215-220.

Woolhouse MEJ 1998. Patterns in parasite epidemiology: the peak shift. Parasitol Today 14: 428-433. 